\title{
Antioxidative effects of whey protein on peroxide-induced cytotoxicity
}

\author{
R. Xu, N. Liu, ${ }^{1} X . X u$, and B. Kong \\ Key laboratory of Dairy Science, Ministry of Education, College of Food Science, Northeast Agricultural University, 59 Mucai Street, \\ Xiangfang District, Harbin 150030, China
}

\begin{abstract}
Myoblastic toxicity is a major adverse effect caused by reactive oxygen species (ROS) when exercising heavily. Although protection or alleviation of ROS toxicity can be achieved by administration of antioxidant vitamins such as vitamin $\mathrm{E}$ and vitamin $\mathrm{C}$, their protective effect remains controversial. Thus, alternative natural antioxidants may be potential candidates for foods for athletes. In this research, we investigated the antioxidative effect of whey protein against hydrogen peroxide $\left(\mathrm{H}_{2} \mathrm{O}_{2}\right)$ toxicity using $\mathrm{C}_{2} \mathrm{C}_{12}$ myoblasts. Whey protein pre-incubation prevented the decrease in cell viability after $\mathrm{H}_{2} \mathrm{O}_{2}$ treatment. The production of 8-hydroxydeoxyguanosine associated with DNA oxidative damage was also inhibited by the whey protein pre-incubation. Endogenous antioxidant defense, such as glutathione, catalase, and superoxide dismutase activity, was also modulated by the antioxidant. At the same time, enhanced mRNA expression levels of heme oxygenase-1 and NADPH quinone oxidoreductase- 1 were observed in cells pre-incubated with whey protein before $\mathrm{H}_{2} \mathrm{O}_{2}$ abuse. These findings suggest that whey protein improved the antioxidant capacity against acute oxidative stress through multiple pathways and this protein may serve as an alternative source of antioxidants for prevention of athletic injuries caused by ROS.
\end{abstract}

Key words: $\mathrm{C}_{2} \mathrm{C}_{12}$ myoblast, antioxidant, hydrogen peroxide, whey protein

\section{INTRODUCTION}

Cell injury associated with reactive oxygen species (ROS) has been implicated in a wide variety of muscle diseases and pathologic conditions (Jackson and O'Farrell, 1993). Skeletal muscle is susceptible to ROS injury even under physiological condition because rapid changes in energy supply and oxygen flux occur during the contractions. Oxidative stress is believed to contribute to numerous pathological conditions, including aging and fatigue of skeletal muscles. The potential

Received October 3, 2010.

Accepted March 30, 2011.

${ }^{1}$ Corresponding author: ningliu6666@yahoo.com.cn sources of free radical generation in exercising muscle are mainly from mitochondria, xanthine oxidase, catecholamines, $\mathrm{NAD}(\mathrm{P}) \mathrm{H}$ oxidase, and secondary sources such as phagocytosis or calcium accumulation. Although free radical formation in humans cannot be measured directly, indirect evidence strongly suggests that at least high-intensity, long-duration exercise leads to increased formation of free radicals (Sjödin et al., 1990; Sen, 1995). Physical exercise requires ATP as an energy source, which is primarily produced by oxidative phosphorylation. Re-oxygenation or reperfusion with oxygenated blood results in local and systemic effects, which may cause more tissue damage. Moreover, extreme exercise leads to muscle injury by increased production of ROS (Davies et al., 1982). The mechanism of delayed muscle damage after intense physical activity is not fully understood, but it has been suggested that such delayed injury occurs because of an inflammatory reaction induced by phagocyte infiltration that is triggered by excessive mechanical stress (Komulainen et al., 1998) and oxidative stress (Aoi et al., 2004). Thus, the enhancement of antioxidative potential of skeletal muscles will have an advantage in preparing for the redox imbalance occurring under exercise conditions or in diseases. Whey protein contains cysteine-rich protein and functions as a cysteine donor system in cells (Walzem et al., 2002); moreover, glutamine represents, on average, 4 to $5 \%$ of total AA. The glutathione (GSH) antioxidant system is important among the cellular protection systems. Glutathione participates directly in the destruction of ROS and maintains ascorbic acid and tocopherol in reduced active forms. Depletion of GSH is a common consequence of increased formation of free radicals. This phenomenon can take place in the muscle cell during exercise (Bounous, 2000). Lands et al. (1999) reported lymphocyte GSH, measured as an index of intracellular GSH, was significantly increased in the whey-supplemented group. Whey protein has been demonstrated to selectively manipulate GSH levels in normal or cancer cells and has been shown to be a potent modulator of cellular immune functions (Bounous, 2000). Gad et al. (2011) demonstrated that whey proteins have free radical scavenging properties and antioxidant activity. It is generally believed that increases 
in free radical production occur in conjunction with decreases in GSH levels (Kent et al., 2003). To decrease the damage induced by free radicals, the antioxidant enzymes play important roles in organisms. The initial effect of oxidative stress leads to activation of a battery of defensive gene expression that leads to detoxification of ROS and prevention of free radical generation and cell survival. Of these genes, some are enzymes, such as NADPH quinone oxidoreductase-1 (NQO1) and heme oxygenase-1 (HO-1). A wide variety of factors are associated with the cellular response to oxidative stress. For example, NF-E2-related factor 2 (Nrf2) promotes cell survival. The Nrf2 is a nuclear transcription factor that controls the expression and coordinated induction of a battery of defensive genes encoding detoxifying enzymes and antioxidant proteins. This is a mechanism of critical importance for cellular protection and cell survival. The Nrf2 pathway is regarded as the most important in the cell to protect against oxidative stress (Jaiswal, 2004).

Based on the evidence above, we decided to investigate the antioxidant effects of whey protein for the protection of myoblasts from hydrogen peroxide $\left(\mathrm{H}_{2} \mathrm{O}_{2}\right)$ toxicity.

\section{MATERIALS AND METHODS}

\section{Materials}

The $\mathrm{C}_{2} \mathrm{C}_{12}$ myoblasts were purchased from the China Center for Type Culture Collection (Wuhan, Hubei). Dulbecco's modified Eagle's medium (DMEM) and fetal bovine serum (FBS) were purchased from Gibco (Grand Island, NY). The whey protein content was $80.05 \mathrm{~g} / 100 \mathrm{~g}$, which was measured using the Kjeldahl method.

\section{Cell Culture}

The cells were grown in DMEM containing $10 \mathrm{~mL}$ of FBS per $100 \mathrm{~mL}$ of culture medium. All cultures were kept in a humidified atmosphere of $95 \%$ air and $5 \%$ $\mathrm{CO}_{2}$ at $37^{\circ} \mathrm{C}$. Initially, the cells were cultured for $1 \mathrm{~d}$ in $3 \mathrm{~mL}$ of DMEM, which was supplemented with $10 \mathrm{~mL}$ of FBS per $100 \mathrm{~mL}$ of culture medium. In the cell viability experiment, $\mathrm{C}_{2} \mathrm{C}_{12}$ myoblasts were cultivated for $24 \mathrm{~h}$ with or without whey protein. The cultures were washed with $2 \mathrm{~mL}$ of DMEM, and subsequently, the culture media were replaced with $0.25,0.5,0.75$, and $1 \mathrm{mmol} / \mathrm{L}$ of $\mathrm{H}_{2} \mathrm{O}_{2}$. The control was cultured without $\mathrm{H}_{2} \mathrm{O}_{2}$ in DMEM.

\section{Cell Viability}

Cell viability was determined by the 3,(4,5-dimethylthiazol-2-yl)2,5-diphenyltetrazolium bromide (MTT) method (Zhang et al., 2010) according to the MTT assay kit (KeyGEN Biotech Co., Nanjing, China). The myoblasts were cultured with or without whey protein for $24 \mathrm{~h}$ after pre-incubation in growth medium for $24 \mathrm{~h}$ in 96-well plates. Then, $\mathrm{H}_{2} \mathrm{O}_{2}$ was added to the culture and incubated for $30 \mathrm{~min}$. After replacing the medium with $50 \mu \mathrm{L}$ of MTT, the myoblasts were incubated for 4 $\mathrm{h}$ at $37^{\circ} \mathrm{C}$. The cells were lysed using dimethyl sulfoxide, and the absorbance at $550 \mathrm{~nm}$ was measured using a microplate reader (Bio-Rad 680; Bio-Rad Laboratories, Hercules, CA).

\section{Biochemical Assay}

Cell lysates were prepared for the assessment of enzymatic activities and lipid peroxidation. Cell samples were homogenized in lysis buffer containing $100 \mathrm{mM}$ Tris buffer ( $\mathrm{pH} 7.4$ ), $0.2 \mathrm{~mL}$ of Triton X-100 per 100 $\mathrm{mL}$ of lysis buffer, and $1 \mathrm{~m} M$ EDTA. Cell homogenates were then centrifuged at $10,000 \times g$ for $10 \mathrm{~min}$ at $4^{\circ} \mathrm{C}$. The clear supernatant was collected for determination of protein concentrations using the Bradford protein assay kit (Beyotime, Haimen, China).

The extent of cellular lipid peroxidation was determined by measuring the concentration of thiobarbituric acid-reactive substances (TBARS), as described by Menéndez et al. (2002). The absorbance at 532 $\mathrm{nm}$ of the supernatants was measured (DU800 spectrophotometer; Beckman Coulter Inc., Brea, CA). The TBARS values are expressed as malondialdehyde (MDA) equivalencies (nmol of $\mathrm{MDA} / \mathrm{mg}$ of protein).

The determination of GSH uses a kinetic enzymatic recycling reaction, based on the oxidation of GSH by 5,5'-dithiobis(2-nitrobenzoic acid) (DNTB; Vandeputte et al., 1994). The samples were added to the microplate wells, followed by DNTB and GSH reductase. Addition of NADPH to the wells initiated the progressive reduction of DNTB by GSH, causing a color increase that was monitored at $415 \mathrm{~nm}$.

Superoxide dismutase (SOD) catalyzes the conversion of superoxide anion radical to $\mathrm{H}_{2} \mathrm{O}_{2}$ and molecular oxygen. The enzyme activity can be measured based on the dismutation of superoxide anion radical generated by non-enzymatic systems (Ewing and Janero, 1995). The reaction was monitored at $550 \mathrm{~nm}$. Cellular SOD activities are expressed in units of $\mathrm{U} / \mathrm{mg}$ of protein.

The catalase (CAT) assay uses the peroxidation function of CAT for the determination of enzyme activity. This method is based on the reaction of the enzyme with $\mathrm{H}_{2} \mathrm{O}_{2}$ in the presence of an optimal concentration of ammonium molybdate. The absorbance was read at $550 \mathrm{~nm}$ using a Beckman model DU800 spectrophotometer. The assay was performed according to the manu- 
facturer's instructions. Catalase activities are expressed in $\mathrm{U} / \mathrm{mg}$ of protein.

Glutathione peroxidase (GSH-Px) was determined spectrophotometrically in cell homogenates using the method of Lawrence and Burk (1976).

The detection kits were all purchased from Nanjing Jiancheng Bioengineering Institute (Nanjing, China).

\section{Determination of 8-Hydroxydeoxyguanosine Concentration}

In this study, the 8-hydroxydeoxyguanosine (8OHdG) concentration was determined with an ELISA kit (R\&D Systems China Co. Ltd., Shanghai) according to the reference of Joyce et al. (2009). Briefly, cell supernatants were incubated with the primary antibody for $30 \mathrm{~min}$ at $37^{\circ} \mathrm{C}$, and washed with washing liquid and then incubated with chromogen solution for $15 \mathrm{~min}$ at $37^{\circ} \mathrm{C}$. These mixtures were stopped by the addition of stop solution. The absorbance of the reaction product was read at $450 \mathrm{~nm}$ using a microplate reader (Bio-Rad 680; Bio-Rad Laboratories).

\section{Reverse-Transcription PCR}

Isolation of total RNA and analysis of reverse-transcription PCR were done as follows: briefly, an RNAiso Plus Kit (Takara Biotechnology Co. Ltd., Dalian, China) was used to extract RNA from cells. The total RNA sample $(2 \mu \mathrm{g})$ was reverse transcribed in a $20-\mu \mathrm{L}$ reaction volume using gene-specific primer and Fermentas reverse-transcription kit (MBI Fermentas, Burlington, ON, Canada) according to the manufacturer's instructions. The primers were designed and purchased from Taihegene Corporation (Beijing, China). The PCR products were separated by agarose gel electrophoresis to determine the product of PCR. For quantitative evaluation of the gene expression levels, a relative frequency for the expression of the target gene against the GAPDH gene was calculated for standardization.

\section{Statistical Analysis}

Results are expressed as mean \pm standard error. The Student's t-test or ANOVA was used to compare quantitative data populations with normal distributions and equal variance. A value of $P<0.05$ was considered statistically significant, unless otherwise specified.

\section{RESULTS}

\section{Cell Viability}

The viability of $\mathrm{C}_{2} \mathrm{C}_{12}$ myoblasts after oxidative abuse by $\mathrm{H}_{2} \mathrm{O}_{2}$ was determined by MTT assay. $\mathrm{H}_{2} \mathrm{O}_{2}$-induced cell death occurred in a dose-dependent manner for the control cultures without whey protein pre-incubation (Figure 1A). In contrast, the cell death by $\mathrm{H}_{2} \mathrm{O}_{2}$ was alleviated by the pretreatment of cells with $0.4 \mathrm{mg} /$ $\mathrm{mL}$ of whey protein. The preventive effect of whey protein on $\mathrm{H}_{2} \mathrm{O}_{2}$-induced cell death was examined at various concentrations of whey protein at fixed $\mathrm{H}_{2} \mathrm{O}_{2}$ concentration (Figure 1B). Cell viability was recovered significantly with increasing concentrations of whey protein from 0.1 to $0.4 \mathrm{mg} / \mathrm{mL}$. These results indicate that the antioxidant potential of $\mathrm{C}_{2} \mathrm{C}_{12}$ myoblasts was definitely modulated by whey protein pretreatment, and thus, the cells were rescued from the death induced by $\mathrm{H}_{2} \mathrm{O}_{2}$ abuse.

\section{Biochemical Assay}

Table 1 shows the effects of $\mathrm{H}_{2} \mathrm{O}_{2}$ and whey protein on lipid peroxidation of $\mathrm{C}_{2} \mathrm{C}_{12}$ myoblasts. Incubation of $\mathrm{C}_{2} \mathrm{C}_{12}$ cells with whey protein alone did not change the basal level of the lipid peroxide derivative MDA. In contrast, $\mathrm{H}_{2} \mathrm{O}_{2}$ treatment significantly elevated the MDA content 2.3-fold compared with the control. Interestingly, whey protein decreased lipid peroxidation to a level lower than the control level.

Glutathione was determined to evaluate the effects of exogenous antioxidant on the cellular GSH reservoir. Whey protein treatment alone increased the GSH level in the myoblasts by 2.1-fold. Hydrogen peroxide markedly decreased the GSH content to 0.38 -fold of the control level. Despite the presence of $\mathrm{H}_{2} \mathrm{O}_{2}$ in the culture medium, whey protein markedly increased GSH level to 1.7-fold from the control level.

Hydrogen peroxide treatment significantly decreased GSH-Px activity (0.72-fold). On the other hand, $\mathrm{C}_{2} \mathrm{C}_{12}$ cell incubation with whey protein alone increased the enzyme activity and this effect was sustained even in the presence of $\mathrm{H}_{2} \mathrm{O}_{2}$ compared with the $\mathrm{H}_{2} \mathrm{O}_{2}$ group.

Hydrogen peroxide significantly decreased the endogenous antioxidant enzyme activities of CAT and SOD. Whey protein increased CAT activity both in the presence and absence of $\mathrm{H}_{2} \mathrm{O}_{2}$. Treatment with whey protein alone significantly enhanced SOD activity, and the effect was sustained even in the presence of $\mathrm{H}_{2} \mathrm{O}_{2}$ (Table 1).

\section{Detection of 8-OHdG}

By ELISA, 8-OHdG formation was measured in the culture medium of $\mathrm{C}_{2} \mathrm{C}_{12}$ cells with or without treatment by whey protein (Figure 2). When cells were exposed to $\mathrm{H}_{2} \mathrm{O}_{2}$ abuse, 8-OHdG increased dramatically. This formation was significantly inhibited by the addition of whey protein to the cells before treatment by $\mathrm{H}_{2} \mathrm{O}_{2}$. 
Table 1. Protective effect of whey protein on $\mathrm{C}_{2} \mathrm{C}_{12}$ cells from oxidative damage ${ }^{1}$

\begin{tabular}{lccccc}
\hline & $\begin{array}{c}\text { MDA } \\
\text { (nmol/mg } \\
\text { of protein) }\end{array}$ & $\begin{array}{c}\text { GSH } \\
\text { (mg/g of } \\
\text { protein })\end{array}$ & $\begin{array}{c}\text { SOD } \\
(\mathrm{U} / \mathrm{mg} \text { of protein })\end{array}$ & $\begin{array}{c}\text { CAT } \\
\text { (U/mg of } \\
\text { protein) }\end{array}$ & $\begin{array}{c}\text { GSH-Px } \\
(\mathrm{U} / \mathrm{mg} \text { of protein })\end{array}$ \\
\hline Control & $2.16 \pm 0.15$ & $0.44 \pm 0.03$ & $13.4 \pm 0.82$ & $27.2 \pm 1.3$ & $101.3 \pm 1.5$ \\
Whey protein & $1.98 \pm 0.12$ & $0.92 \pm 0.05^{*}$ & $19.4 \pm 0.6^{*}$ & $28.3 \pm 1.6$ & $105.6 \pm 1.6$ \\
$\mathrm{H}_{2} \mathrm{O}_{2}$ & $5.03 \pm 0.11^{*}$ & $0.17 \pm 0.01^{*}$ & $5.27 \pm 0.41^{*}$ & $15.1 \pm 0.7^{*}$ & $72.9 \pm 1.9^{*}$ \\
Whey protein $\mathrm{H}_{2} \mathrm{H}_{2} \mathrm{O}_{2}$ & $1.67 \pm 0.23 \dagger$ & $0.75 \pm 0.08 \dagger$ & $11.7 \pm 0.5 \dagger$ & $23.7 \pm 1.3 \dagger$ & $87.5 \pm 2.1 \dagger$ \\
\hline
\end{tabular}

${ }^{1}$ Data are presented as means \pm standard errors, obtained from at least triplicate determinations. MDA $=$ malondialdehyde; $\mathrm{GSH}=$ glutathione; $\mathrm{SOD}=$ superoxide dismutase; CAT $=$ catalase; $\mathrm{GSH}-\mathrm{Px}=$ glutathione peroxidase.

*Statistically significant difference from the control; †significantly different from the $\mathrm{H}_{2} \mathrm{O}_{2}$ treatment $(P<$ $0.05)$.
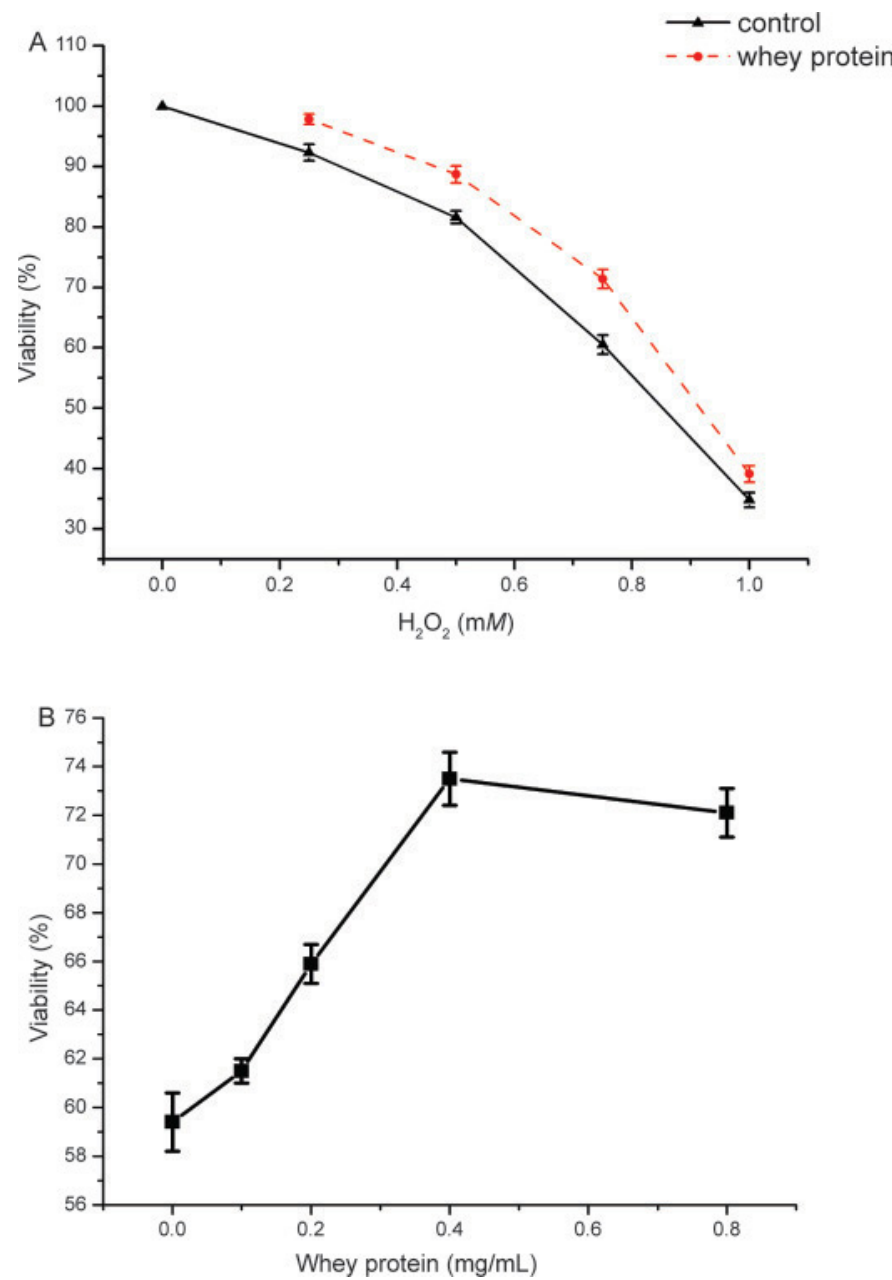

Figure 1. Viability of $\mathrm{C}_{2} \mathrm{C}_{12}$ myoblasts. A: Dose-dependent effect of $\mathrm{H}_{2} \mathrm{O}_{2}$ on cell viability of $\mathrm{C}_{2} \mathrm{C}_{12}$ myoblasts. After the pre-incubation with or without whey protein $(0.4 \mathrm{mg} / \mathrm{mL})$ for $24 \mathrm{~h}$, myoblast cultures were treated with different concentrations of $\mathrm{H}_{2} \mathrm{O}_{2}$, as indicated, for $1 \mathrm{~h}$. B: Effect of whey protein concentration on cell viability of myoblasts. After pre-incubation with whey protein, at the indicated concentration, myoblast cultures were treated with $0.75 \mathrm{mM} \mathrm{H}_{2} \mathrm{O}_{2}$ for $1 \mathrm{~h}$. Each value represents the mean \pm standard error obtained from at least triplicate determinations. Color version available in the online PDF.

\section{mRNA Expression}

We examined the induction of HO-1, NQO1, and Nrf2 genes by conducting a reverse transcription PCR experiment, in which the cells were cultured in medium containing $0.75 \mathrm{mM} \mathrm{H}_{2} \mathrm{O}_{2}$ for $1 \mathrm{~h}$ with or without whey protein pretreatment (Figure 3). The expression level of HO-1 mRNA in the $\mathrm{H}_{2} \mathrm{O}_{2}$ group was a little lower than the control cells, and then started to increase in the whey protein-treated cells (Table 2). The Nrf2 target genes include HO-1 and NQO1, collectively being referred to as the Nrf2 regulon (Kobayashi and Yamamoto, 2006). The Nrf2 binds to the antioxidant response element, promoting transcription of various cytoprotective genes (Itoh et al., 1997). Treatment of the cells with whey protein indeed enhanced the HO-1, NQO1, and Nrf2 mRNA expression in $\mathrm{C}_{2} \mathrm{C}_{12}$ cells; all of that may be regulated by the Nrf2-dependent pathway.

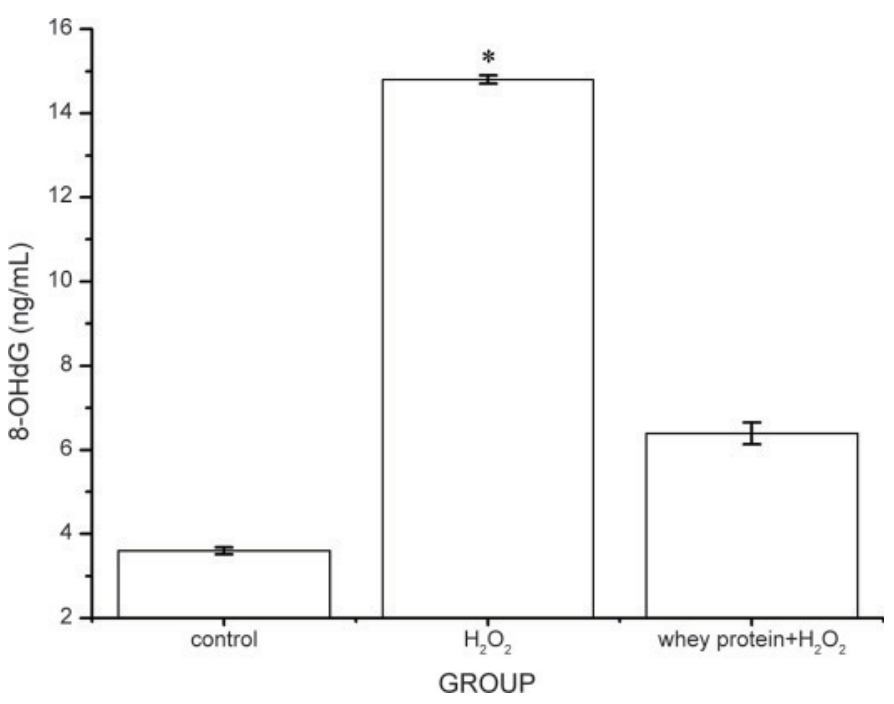

Figure 2. Effect of whey protein on 8-hydroxydeoxyguanosine (8OHdG) formation by $\mathrm{H}_{2} \mathrm{O}_{2}$ in $\mathrm{C}_{2} \mathrm{C}_{12}$ cells. Cells were incubated with $0.5 \mathrm{mM} \mathrm{H}_{2} \mathrm{O}_{2}$ in the absence or the presence of whey protein $(0.4 \mathrm{mg} /$ $\mathrm{mL})$ at $37^{\circ} \mathrm{C}$ for $24 \mathrm{~h}$. Then, the 8 -OHdG concentration was determined. Results are expressed as the mean \pm standard error. ${ }^{*} P<0.05$. 
Table 2. Relative expression of $\mathrm{mRNA}^{1}$

\begin{tabular}{llll}
\hline Group & \multicolumn{1}{c}{ Nrf2 } & \multicolumn{1}{c}{ HO- 1} & \multicolumn{1}{c}{ NQO1 } \\
\hline Control & $0.681 \pm 0.02$ & $1.120 \pm 0.003$ & $0.94 \pm 0.01$ \\
$\mathrm{H}_{2} \mathrm{O}_{2}$ & $0.863 \pm 0.006$ & $0.802 \pm 0.002^{*}$ & $0.56 \pm 0.009^{*}$ \\
Whey protein $+\mathrm{H}_{2} \mathrm{O}_{2}$ & $0.930 \pm 0.03^{*}$ & $1.030 \pm 0.02 \dagger$ & $1.01 \pm 0.03$ \\
\hline
\end{tabular}

${ }^{1}$ Data are presented as means \pm standard errors obtained from at least triplicate determinations. Nrf2 $=\mathrm{NF}-$ E2-related factor 2; HO-1 = heme oxygenase-1; NQO1 = NADPH quinone oxidoreductase-1.

*Statistically significant difference from the control; ${ }^{\dagger}$ significantly different from the $\mathrm{H}_{2} \mathrm{O}_{2}$ treatment $(P<$ $0.05)$.

\section{DISCUSSION}

In the cytotoxic assessment, the result with the viability of cells revealed that even though in high-dose treatment of whey protein, a slight decrease was shown. The reasons for the lack of significant increase in cell viability with high doses of whey protein are still

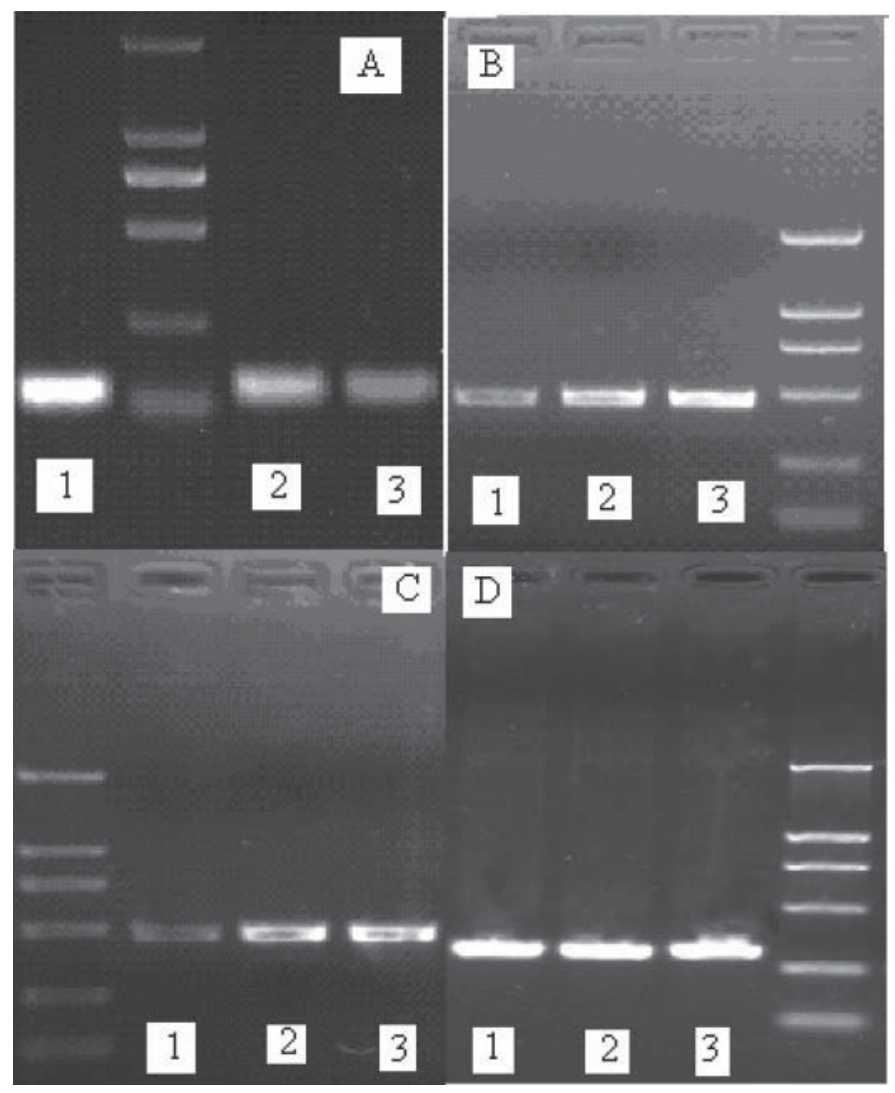

Figure 3. The mRNA expression of NF-E2-related factor 2 (Nrf2), heme oxygenase-1 (HO-1), and NADPH quinone oxidoreductase-1 (NQO1) in $\mathrm{C}_{2} \mathrm{C}_{12}$ myoblasts. After pre-incubation with or without whey protein for $24 \mathrm{~h}$, myoblast cultures were treated with $0.75 \mathrm{mM}$ $\mathrm{H}_{2} \mathrm{O}_{2}$. A: Nrf2 gel electrophoresis image; lanes 1 to 3 represent whey $+\mathrm{H}_{2} \mathrm{O}_{2}, \mathrm{H}_{2} \mathrm{O}_{2}$, and the control group, respectively; B: HO-1 gel electrophoresis image; lanes 1 to 3 represent $\mathrm{H}_{2} \mathrm{O}_{2}$, whey $+\mathrm{H}_{2} \mathrm{O}_{2}$, and the control group, respectively; $\mathrm{C}$ : NQO1 gel electrophoresis image: lanes 1 to 3 represent $\mathrm{H}_{2} \mathrm{O}_{2}$, whey $+\mathrm{H}_{2} \mathrm{O}_{2}$, and the control group, respectively; D: GAPDH gel electrophoresis image; lanes 1 to 3 represent $\mathrm{H}_{2} \mathrm{O}_{2}$, whey $+\mathrm{H}_{2} \mathrm{O}_{2}$, and the control group, respectively. unknown. This might be related to the antioxidative mechanisms of whey protein in the $\mathrm{C}_{2} \mathrm{C}_{12}$ cell. Therefore, we could not perceive the protective function of cells with the addition of whey protein after the acute exposure of $\mathrm{H}_{2} \mathrm{O}_{2}$, which means the addition of whey protein could be not regarded as the protective agent if one intended to achieve the effect within a short period of time. This might be attributed to shorter duration of the addition of whey protein, so that not enough time was allowed to promote the protective capability of protecting the cells against $\mathrm{H}_{2} \mathrm{O}_{2}$-mediated deleterious effects. In the future, we will investigate whether the prolonged treatment of whey protein can lead to an increase in the cell viability after acute treatment with $\mathrm{H}_{2} \mathrm{O}_{2}$.

Excessive oxides lead readily to oxidative stress, depleting tissues of GSH and impairing antioxidant defense systems in humans. How to increase the level of GSH becomes important. In this experiment, we observed that the levels of GSH had a marked increase in the groups with or without the exposure to $\mathrm{H}_{2} \mathrm{O}_{2}$. The results for the potential mechanism of the promoting production of GSH by whey protein might reveal that the GSH-promoting activity of whey protein might contribute to a broader biological effect of a protective nature with regard to the general detoxification of environmental agents. No evidence was found that GSH was able to pass through cell membranes freely; thus, whey protein must modulate GSH levels by stimulating cells to synthesize GSH intracellularly. The results indicate that whey protein, a potential antioxidant, does protect cells from oxidative stress damage, and the protection includes its capacity to stimulate GSH synthesis.

The antioxidative effects of whey protein were evaluated by a significant increase in cell viability and inhibition of lipid peroxidation. It is well documented that oxidative stress commonly leads to the accumulation of the key cytotoxic lipid peroxide MDA. The cytoprotective effect of antioxidants against $\mathrm{H}_{2} \mathrm{O}_{2}$ is usually associated with the inhibition of lipid peroxidation, regardless of the type and structure of antioxidant.

In addition to the inhibition of lipid peroxidation, the cytoprotective effects of whey protein may occur 
in part through the increase of antioxidant substances. Major intracellular antioxidant defenses are the GSH pool and ROS-scavenging enzymes such as CAT, GSH$\mathrm{Px}$, and SOD. Increased levels or activation of these endogenous antioxidants or enzymes have been shown to protect cells against oxidative damage. Whey protein increased GSH, CAT, and SOD activity to levels substantially higher than those of controls and these effects remained in the presence of $\mathrm{H}_{2} \mathrm{O}_{2}$. Glutathione peroxidase is responsible for the reduction of GSSG to GSH. It is believed that this system is responsible for the maintenance of the GSH/GSSG redox status, which is an important component of cellular antioxidant defense mechanisms. Therefore, maintaining a high cellular GSH/GSSG ratio can provide optimal protection against oxidant-induced cell damage. In our study, we found that the activity of GSH-Px and the level of GSH were increased by the supplement of whey protein in the $\mathrm{C}_{2} \mathrm{C}_{12}$ cell line with $\mathrm{H}_{2} \mathrm{O}_{2}$ treatment. On the whole, the activities of GSH-Px, SOD, and CAT were elevated by the supplement of whey protein; thus, the antioxidant capacity of $\mathrm{C}_{2} \mathrm{C}_{12}$ might be elevated by the supplement of whey protein, and the influences of $\mathrm{H}_{2} \mathrm{O}_{2}$ on SOD and CAT were more significant than that of GSH-Px in this study. As mentioned above, the supplement of whey protein seems to decrease the $\mathrm{H}_{2} \mathrm{O}_{2}$-induced damage through the elevated GSH. Glutathione could attenuate the $\mathrm{H}_{2} \mathrm{O}_{2}$-induced adverse effects by directly scavenging the free radicals derived from the body metabolization. In this study, a marked decrease indeed occurred in the level of GSH in the control group after the treatment with $\mathrm{H}_{2} \mathrm{O}_{2}$; as a result, the decreased levels of GSH might be attributed to the less decreased activity of GSH-Px. The imbalance of the $\mathrm{H}_{2} \mathrm{O}_{2}$-induced antioxidant status in $\mathrm{C}_{2} \mathrm{C}_{12}$, such as the changes in the activity of antioxidant enzymes and the depletion of GSH, might be major causes of cell injury. Nevertheless, the cytoprotective effects of whey protein may be mediated, in part, by activation of Nrf2, a redox-regulated transcription factor that binds to the antioxidant response element (ARE). The ARE is a cis-acting enhancer sequence that regulates transcriptional activation of stress-induced genes, including SOD and phase II detoxifying enzymes. This study demonstrated that treatment with whey protein improved Nrf2 expression and $\mathrm{C}_{2} \mathrm{C}_{12}$ cell viability.

The oxidative DNA damage marker, $8-\mathrm{OHdG}$, was increased in $\mathrm{H}_{2} \mathrm{O}_{2}$-induced cells. Ichinose et al. (1997) have shown that the formation of $8-\mathrm{OHdG}$ in mouse DNA was detected, suggesting that the active oxygen radicals induced the formation of $8-\mathrm{OHdG}$ in mouse lung DNA. It is presumed that the free radicals derived enzymatically in cells could be related to the formation of 8 -OHdG or cell toxicity. Because the hydroxylation of guanine residues in DNA is thought to be involved in mutagenesis and carcinogenesis, the generation of ROS during physiologic reaction may be contribute to the observed 8-OHdG production in vivo.

Protection against ROS-mediated cell injury could be achieved through the induction of phase 2 detoxifying enzymes and antioxidant enzymes such as NQO1 and HO- 1 , a process that is mediated mainly by the ARE within the promoter regions of these genes (Wielandt et al., 2006; Nguyen et al., 2009). The Nrf2-ARE pathway plays a pivotal role in the cellular defense against the cellular damage caused by ROS.

Heme oxygenase-1 activity may have either protective effect or toxic effect against oxidative stress in various cells, depending upon the cell population and the type of injury. Many reports have demonstrated that HO-1 has potent antioxidant and anti-apoptotic activities (Chen et al., 2000), whereas some others have indicated that reactive iron, a HO-1 product, has a potent cytotoxic effect (Suttner and Dennery, 1999). To minimize oxidative damage to cellular components, cells have evolved several antioxidant defenses. For example, endogenous cellular antioxidant GSH and NQO1, two of the extensively investigated phase 2 enzymes, have been demonstrated to play important roles in protecting cells against oxidative stress. The MTT assay showed that whey protein could prevent the cell death of $\mathrm{C}_{2} \mathrm{C}_{12}$ due to oxidative stress, suggesting that whey protein-induced HO-1 likely acted not as an inducer of cell death. To prevent oxidation, antioxidants are used to induce several genes encoding antioxidant proteins (Arisawa et al., 2009; Di Domenico et al., 2009). The ARE is present in the promoter region of genes encoding antioxidant enzymes such as HO-1 and NQO1; other antioxidant enzymes such as SOD and CAT and nonenzymatic scavengers such as GSH are also involved in scavenging ROS (Johnson et al., 2008). In our study, the upregulation of several antioxidative enzymes is associated with the decreased formation of ROS and enhanced survival of $\mathrm{C}_{2} \mathrm{C}_{12}$ cells upon the induction of oxidative stress. The ARE sites are known to be regulated by the antioxidative transcription factor Nrf2. High ROS levels result in the stabilization of Nrf2 and, consequently, transcriptional activation of numerous endogenous antioxidants via ARE sites (Jaiswal, 2004). The stabilization of Nrf2 and subsequent transcriptional activation of glutathione have been shown in different cell types in early studies (Stewart et al., 2003). Here, we observed the induction of Nrf2 mRNA levels and Nrf2-dependent transcriptional activation of antioxidative enzymes in $\mathrm{C}_{2} \mathrm{C}_{12}$ cells upon treatment with whey protein. Taken together, our observations clearly indicate an essential role for Nrf2 in the mediation of upregulation of antioxidative enzymes and 
subsequent myoblast protection. Studies have demonstrated that a variety of cellular antioxidants and phase 2 enzymes, especially GSH and NQO1, can protect neuronal cells against oxidative damage (Siegel et al., 1997). In this context, the coordinated induction of endogenous GSH and NQO1 via the use of whey protein appears to be a promising strategy for protecting against oxidative damage. The results of the present study demonstrated that incubation of $\mathrm{C}_{2} \mathrm{C}_{12}$ cells with whey protein resulted in significant induction of the cellular antioxidant GSH and phase 2 enzyme HO-1 in the $\mathrm{H}_{2} \mathrm{O}_{2}$ abuse condition. However, the same treatment of $\mathrm{C}_{2} \mathrm{C}_{12}$ cells under the present experimental conditions failed to significantly induce another phase 2 enzyme NQO1, indicating that in $\mathrm{C}_{2} \mathrm{C}_{12}$ cells, different antioxidants and phase 2 enzymes might be regulated via distinct signaling pathways. In this context, our studies demonstrated that GSH and HO-1 are the 2 most inducible cellular defenses following treatment with whey protein. The exact signaling mechanism by which whey protein mediates elevation of GSH and HO-1 in $\mathrm{C}_{2} \mathrm{C}_{12}$ cells remains to be defined. The Nrf2 has been reported to be a critical transcriptional activator for a variety of antioxidants and phase 2 genes, especially NQO1, in various types of tissues and cells (Zhu et al., 2006). Whether such an Nrf2-dependent mechanism is also involved in whey protein-induced elevation of GSH and $\mathrm{HO}-1$ in $\mathrm{C}_{2} \mathrm{C}_{12}$ cells warrants further investigation.

\section{CONCLUSIONS}

Our results suggest that whey protein improved the antioxidant capacity against acute oxidative stress through multiple pathways. The balance between the survival signals and death signals is crucial in the determination of cell fate. Whey protein enhanced survival factors through elevation of GSH, activation of CAT/SOD enzyme activity, and inhibition of lipid peroxidation. This study suggests that whey protein may serve as an alternative antioxidant for prevention of $\mathrm{H}_{2} \mathrm{O}_{2}$ cytotoxicity. Further studies should identify the potential ROS-related therapeutic implications.

\section{ACKNOWLEDGMENTS}

This work was supported by Grant No. CXT007-3-1 from the Innovative Team of Developmental Science and Technology of Bio-Dairy Products, Northeast Agricultural University (Harbin, China), and Grant No.2010td11 from the Innovative Research Team of Higher Education of Heilongjiang Province, China.

\section{REFERENCES}

Aoi, W., Y. Naito, Y. Takanami, Y. Kawai, K. Sakuma, H. Ichikawa, N. Yoshida, and T. Yoshikawa. 2004. Oxidative stress and delayed-onset muscle damage after exercise. Free Radic. Biol. Med. $37: 480-487$.

Arisawa, S., K. Ishida, N. Kameyama, J. Ueyama, A. Hattori, Y. Tatsumi, H. Hayashi, M. Yano, K. Hayashi, Y. Katano, H. Goto, K. Takagi, and S. Wakusawa. 2009. Ursodeoxycholic acid induces glutathione synthesis through activation of PI3K/Akt pathway in HepG2 cells. Biochem. Pharmacol. 77:858-866.

Bounous, G. 2000. Whey protein concentrate (WPC) and glutathione modulation in cancer treatment. Anticancer Res. 20:4785-4792.

Chen, K., K. Gunter, and M. D. Maines. 2000. Neurons overexpressing heme oxygenase-1 resist oxidative stress-mediated cell death. J. Neurochem. 75:304-313.

Davies, K. J., A. T. Quintanilha, G. A. Brooks, and L. Packer. 1982. Free radicals and tissue damage produced by exercise. Biochem. Biophys. Res. Commun. 107:1198-1205.

Di Domenico, F., M. Perluigi, C. Foppoli, C. Blarzino, R. Coccia, F. De Marco, D. A. Butterfield, and C. Cini. 2009. Protective effect of ferulic acid ethyl ester against oxidative stress mediated by UVB irradiation in human epidermal melanocytes. Free Radic. Res. 43:365-375.

Ewing, J. F., and D. R. Janero. 1995. Microplate superoxide dismutase assay employing a nonenzymatic superoxide generator. Anal. Biochem. 232:243-248.

Gad, A. S., Y. A. Khadrawy, A. A. El-Nekeety, S. R. Mohamed, N. S. Hassan, and M. A. Abdel-Wahhab. 2011. Antioxidant activity and hepatoprotective effects of whey protein and Spirulina in rats. Nutrition 27:582-589.

Ichinose, T., Y. Yajima, M. Nagashima, S. Takenoshita, Y. Nagamachi, and M. Sagai. 1997. Lung carcinogenesis and formation of 8-hydroxy-deoxyguanosine in mice by diesel exhaust particles. Carcinogenesis 18:185-192.

Itoh, K., T. Chiba, S. Takahashi, T. Ishii, K. Igarashi, Y. Katoh, T. Oyake, N. Hayashi, K. Satoh, I. Hatayama, M. Yamamoto, and Y. Nabeshima. 1997. An Nrf2/small Maf heterodimer mediates the induction of phase II detoxifying enzyme genes through antioxidant response elements. Biochem. Biophys. Res. Commun. 236:313-322.

Jackson, M. J., and S. O'Farrell. 1993. Free radicals and muscle damage. Br. Med. Bull. 49:630-641.

Jaiswal, A. K. 2004. Nrf2 signaling in coordinated activation of antioxidant gene expression. Free Radic. Biol. Med. 36:1199-1207.

Johnson, J. A., D. A. Johnson, A. D. Kraft, M. J. Calkins, R. J. Jakel, M. R. Vargas, and P. C. Chen. 2008. The Nrf2-ARE pathway: An indicator and modulator of oxidative stress in neurodegeneration. Ann. N. Y. Acad. Sci. 1147:61-69.

Joyce, N. C., C. C. Zhu, and D. L. Harris. 2009. Relationship among oxidative stress, DNA damage, and proliferative capacity in human corneal endothelium. Invest. Ophthalmol. Vis. Sci. 50:2116-2122.

Kent, K. D., W. J. Harper, and J. A. Bomser. 2003. Effect of whey protein isolate on intracellular glutathione and oxidant-induced cell death in human prostate epithelial cells. Toxicol. In Vitro $17: 27-33$.

Kobayashi, M., and M. Yamamoto. 2006. Nrf2-Keap1 regulated of cellular defense mechanisms against electrophiles and reactive oxygen species. Adv. Enzyme Regul. 46:113-140.

Komulainen, J., T. E. S. Takala, H. Kuipers, and M. K. Hesselink. 1998. The disruption of myofibre structures in rat skeletal muscle after forced lengthening contractions. Pflugers Arch. 436:735-741.

Lands, L. C., V. L. Grey, and A. A. Smountas. 1999. Effect of supplementation with a cysteine donor on muscular performance. J. Appl. Physiol. 87:1381-1385.

Lawrence, R. A., and R. F. Burk. 1976. Glutathione peroxidase activity in selenium-deficient rat liver. Biochem. Biophys. Res. Commun. 71:952-958. 
Menéndez, R., R. Más, A. M. Amor, N. Ledón, J. Pérez, R. M. González, I. Rodeiro, M. Zayas, and S. Jiménez. 2002. Inhibition of rat lipoprotein lipid peroxidation by the oral administration of D003, a mixture of very long-chain saturated fatty acids. Can. J. Physiol. Pharmacol. 80:13-21.

Nguyen, T., P. Nioi, and C. B. Pickett. 2009. The Nrf2-antioxidant response element signaling pathway and its activation by oxidative stress. J. Biol. Chem. 284:13291-13295.

Sen, C. K. 1995. Oxidants and antioxidants in exercise. J. Appl. Physiol. 79:675-686.

Siegel, D., E. M. Bolton, J. A. Burr, D. C. Liebler, and D. Ross. 1997. The reduction of alpha-tocopherolquinone by human $\mathrm{NAD}(\mathrm{P}) \mathrm{H}$ : Quinine oxidoreductase: The role of alpha-tocopherolhydroquinone as a cellular antioxidant. Mol. Pharmacol. 52:300-305.

Sjödin, B., Y. Hellsten Westing, and F. S. Apple. 1990. Biochemical mechanisms for oxygen free radical formation during exercise. Sports Med. 10:236-254.

Stewart, D., E. Killeen, R. Naquin, S. Alam, and J. Alam. 2003. Degradation of transcription factor Nrf2 via the ubiquitin-proteasome pathway and stabilization by cadmium. J. Biol. Chem. 278:23962402.

Suttner, D. M., and P. A. Dennery. 1999. Reversal of HO-1 related cytoprotection with increased expression is due to reactive iron. FASEB J. 13:1800-1809.
Vandeputte, C., I. Guizon, I. Genestie-Denis, B. Vannier, and G. Lorenzon. 1994. A microtiter plate assay for total glutathione and glutathione disulfide contents in cultured/isolated cells: Performance study of a new miniaturized protocol. Cell Biol. Toxicol. 10:415-421.

Walzem, R. L., C. J. Dillard, and J. B. German. 2002. Whey components: Millennia of evolution create functionalities for mammalian nutrition. Crit. Rev. Food Sci. Nutr. 42:353-375.

Wielandt, A. M., V. Vollrath, M. Farias, and J. Chianale. 2006. Bucillamine induces glutathione biosynthesis via activation of the transcription factor Nrf2. Biochem. Pharmacol. 72:455-462.

Zhang, J.-Q., Y.-M. Li, T. Liu, W.-T. He, Y.-T. Chen, X.-H. Chen, X. Li, W.-C. Zhou, J.-F. Yi, and Z.-J. Ren. 2010. Antitumor effect of matrine in human hepatoma G2 cells by inducing apoptosis and autophagy. World J. Gastroenterol. 16:4281-4290.

Zhu, H., L. Zhang, K. Itoh, M. Yamamoto, D. Ross, M. A. Trush, J. L. Zweier, and Y. Li. 2006. Nrf2 controls bone marrow stromal cell susceptibility to oxidative and electrophilic stress. Free Radic. Biol. Med. 41:132-143. 